\title{
Aldose Reductase Inhibitor Fidarestat Prevents Diabetic Ocular Complications in Spontaneously Diabetic Torii Rats
}

\author{
Akihiro Kakehashi, ${ }^{*}$, , Mikiko Takezawa ${ }^{1}$, Fumihiko Toyoda ${ }^{1}$, Nozomi Kinoshita ${ }^{1}$, Chiho Kambara ${ }^{1}$, \\ Hiroko Yamagami ${ }^{1}$, Noriaki Kato ${ }^{2}$, San-e Ishikawa ${ }^{3}$, Masanobu Kawakami ${ }^{3}$ and Yasunori Kanazawa ${ }^{4}$ \\ ${ }^{I}$ Department of Ophthalmology, Jichi Medical University, Saitama Medical Center, Japan \\ ${ }^{2}$ Department of Pharmacology, Pharmaceutical Research Laboratories, Sanwa Kagaku Kenkyusho Co., Ltd., Japan \\ ${ }^{3}$ Department of Integrated Medicine I, Jichi Medical University, Saitama Medical Center, Japan \\ ${ }^{4}$ Japanese Diabetes Foundation, Tokyo, Japan
}

\begin{abstract}
We evaluated the effect of an aldose reductase inhibitor, fidarestat, on diabetic retinopathy (DR) and cataract in spontaneously diabetic Torii (SDT) rats. Four rat groups were included: untreated, low- and high-dose (8 and 32 $\mathrm{mg} / \mathrm{kg} /$ day) fidarestat-treated SDT rats, and nondiabetic control Sprague-Dawley rats. DR and cataract were evaluated and retinal and lens sorbitol, reduced glutathione (GSH), ocular fluid vascular endothelial growth factor (VEGF), and urinary 8-hydroxy-2'-deoxyguanosine (8-OHdG) was measured. The incidence rates of DR and cataract were significantly lower in the low- and high-dose fidarestat groups $v s$ the untreated group $(\mathrm{p}<0.001 / \mathrm{p}<0.001)$. Retinal and lens sorbitol levels were lower in the control $(1.1 \pm 0.1 / 3.1 \pm 0.2 \mathrm{nmol} / \mathrm{mg}$ protein $)(\mathrm{p}<0.05 / \mathrm{p}<0.01)$ and low- $(2.7 \pm 1.1 / 30.0 \pm 3.3 \mathrm{nmol} / \mathrm{mg}$ protein) $(\mathrm{p}<0.01 / \mathrm{p}<0.01)$ and high-dose groups $(0.7 \pm 0.2 / 5.9 \pm 0.6 \mathrm{nmol} / \mathrm{mg}$ protein $)(\mathrm{p}<0.001 / \mathrm{p}<0.001)$ vs the untreated group $(23.2 \pm 4.7 / 123.9 \pm 29.6 \mathrm{nmol} / \mathrm{mg}$ protein). Retinal and lens GSH levels were higher in the nondiabetic control $(52.2 \pm 5.8 / 29.0 \pm 2.7 \mu \mathrm{mol} / \mathrm{mg}$ protein) $(\mathrm{p}<0.01 / \mathrm{p}<0.001)$ and the low- $(46.8 \pm 8.2 / 24.7 \pm 2.8 \mu \mathrm{mol} / \mathrm{mg}$ protein) (not significant $(\mathrm{NS}) / \mathrm{p}<0.001)$ and high-dose groups $(63.3 \pm 14.6 / 26.9 \pm 3.6 \mu \mathrm{mol} / \mathrm{mg}$ protein) $(\mathrm{p}<0.05 / \mathrm{p}<0.001) v s$ the untreated group $(30.3 \pm 2.0 / 1.6 \pm 0.4 \mu \mathrm{mol} / \mathrm{mg}$ protein). VEGF levels were lower in the nondiabetic control $(40.4 \pm 10.0 \mathrm{pg} / \mathrm{ml})$ $(\mathrm{p}<0.01)$ and low- $(65.3 \pm 4.5 \mathrm{pg} / \mathrm{ml})(\mathrm{p}<0.05)$ and high-dose groups $(47.7 \pm 10 \mathrm{pg} / \mathrm{ml})(\mathrm{p}<0.001)$ vs the untreated group $(324.7 \pm 76.4 \mathrm{pg} / \mathrm{ml}) .8$-OHdG levels were lower in the nondiabetic control $(0.73 \pm 0.11 \mathrm{ng} / \mathrm{mg}$ creatinine $)(\mathrm{p}<0.01)$ and low$(4.57 \pm 0.42 \mathrm{ng} / \mathrm{mg}$ creatinine) (NS) and high-dose groups $(3.58 \pm 0.70 \mathrm{ng} / \mathrm{mg}$ creatinine) (NS) $v s$ the untreated group $(6.04 \pm 1.28 \mathrm{ng} / \mathrm{ml})$. Fidarestat inhibited activation of the polyol pathway, reduced oxidative stress and VEGF, and prevented DR and cataract in SDT rats.
\end{abstract}

Keywords: Fidarestat, spontaneously diabetic Torii (SDT) rat, diabetic retinopathy, cataract, vascular endothelial growth factor (VEGF).

\section{INTRODUCTION}

Diabetic retinopathy (DR), cataracts, and neovascular glaucoma are three major vision-threatening diabetic ocular complications. Although cataract can be treated surgically, DR eventually progresses to proliferative DR (PDR) accompanied by tractional retinal detachment and/or neovascular glaucoma. PDR and neovascular glaucoma can be treated by laser and vitreous surgery in certain cases, but the postoperative visual function is usually unsatisfactory. Prevention of DR is ideal for preventing blindness in patients with diabetes.

Clinical trials have shown that intensive glycemic control reduces the incidence and progression of DR [1-3]. However, achieving normal glucose homeostasis is not accomplished easily even in patients who are highly compliant. Furthermore, DR continues to develop and progress in well-controlled patients [1-3].

*Address correspondence to this author at the Department of Ophthalmology, Jichi Medical University, Saitama Medical Center, 1-847 Amanuma-cho, Omiya-ku, Saitama-shi, 330-8503, Japan; Tel: +81-48-647-2111; Fax: +81648-5188; E-mail: kakeaki@omiya.jichi.ac.jp
It is necessary to find treatments in addition to those that address glycemic control. Among the metabolic changes accompanying hyperglycemia are increased polyol pathway activity $[4,5]$, activation of protein kinase $\mathrm{C}$ (PKC) [6-8], increased oxidative stress [9-11], and accumulation of advanced glycation end products (AGEs) $[12,13]$ that are related to the development and progression of diabetic ocular complications. In particular, the polyol pathway is correlated strongly with oxidative stress, activation of PKC [7], and accumulation of AGEs that lead to induction of vascular endothelial growth factor (VEGF) [13]. A key enzyme of the polyol pathway, aldose reductase (AR), is found in the retina and lens. AR inhibitors (ARIs) slow thickening of the basement membrane of the retinal capillaries and progression of diabetic cataract in experimental studies [14-21]. The polyol pathway is the most attractive target for adjunctive treatment to prevent diabetic ocular complications. Based on favorable in vivo experiments using the ARI sorbinil [22, 23], a clinical trial of sorbinil was conducted, but the drug did not affect the development of DR [24], and enthusiasm for the clinical application of ARI waned. 
The spontaneously diabetic Torii (SDT) rat, a substrain of the Sprague-Dawley (SD) rat, spontaneously develops diabetes mellitus and exhibits the three major diabetic ocular complications, cataracts, advanced DR, and rubeotic glaucoma. In 1988, five male rats with polyuria and glucosuria were identified among 305 rats from an outbred colony of the Crj:CD (SD) strain (Charles River Japan, Inc., Kanagawa, Japan) of SD rats. After the 20th generation of sister-brother matings, the diabetic strain was established in 1997. The characteristics of this rat are described in this issue. The ARI, fidarestat, has a stronger AR inhibitory effect, longer half-life, and fewer adverse effects on the peripheral nerves than other ARIs [25]. Fidarestat showed strong AR inhibition and prevented diabetic retinal changes in streptozotocin (STZ)-induced diabetic rats, which have early DR [19-21]. Therefore, we evaluated the effects of fidarestat in SDT rats, which develop advanced diabetic ocular complications.

\section{MATERIALS AND METHODS}

The care and handling of the animals were in accordance with the Association for Research in Vision and Ophthalmology Statement for the Use of Animals in Ophthalmic and Visual Research and approved by the Jichi Medical University Animal Care and Use Committee. The male SDT rats and SD rats were obtained from CLEA, Inc., Tokyo, Japan. All SDT rats were confirmed to be diabetic based on a non-fasting blood glucose concentration exceeding $19.4 \mathrm{mmol} / \mathrm{l}$. Four groups of rats were included in the study: untreated SDT rats (18 rats), low-dose fidarestattreated SDT rats $(8 \mathrm{mg} / \mathrm{kg} / \mathrm{day}, 14$ rats), high-dose fidarestattreated SDT rats $(32 \mathrm{mg} / \mathrm{kg} / \mathrm{day}, 21$ rats $)$, and non-diabetic normal control SD rats (10 rats). The high- and low-dose fidarestat-treated SDT rats were fed standard rat chow (CRF1, Oriental Yeast, Inc., Tokyo, Japan) containing the ARI fidarestat at the onset of diabetes. Other rats were fed unsupplemented rat chow. DR was evaluated using fluorescein angiomicroscopy and histopathology.

\section{Measurement of Plasma Glucose and Glycated Hemoglobin}

Blood samples were collected from the abdominal aorta with the animals anesthetized with diethyl ether to measure plasma glucose and glycated hemoglobin. Blood samples were centrifuged at $1,700 \mathrm{xg}$ for 10 minutes at $4^{\circ} \mathrm{C}$ to obtain plasma for measurement by the mutarotase-glucose oxidase method (Glucose CII-test Wako, Wako, Osaka, Japan). Glycated hemoglobin was measured using an automated glycohemoglobin analyzer (HLC-723GHb V, Tosoh Corporation, Tokyo, Japan).

\section{Fluorescein Angiomicrography}

Fluorescein-dextran microscopy was performed after intracardiac injection of fluorescein-dextran (fluorescein isothiocyanate-dextran, Sigma, St. Louis, MO), using a modification of a previously reported method [26]. Under deep anesthesia induced by intraperitoneal injection of pentobarbital sodium $(25 \mathrm{mg} / \mathrm{kg}$ body weight), $1 \mathrm{ml}$ of phosphate buffered saline containing $50 \mathrm{mg}$ of fluoresceindextran was injected into the left ventricle of each animal. After 5 minutes, the eyes were enucleated for fluorescein microscopy. The retina was peeled from the eyecup and the entire retina was flat-mounted on a slide glass without fixation. A drop of aqueous mounting medium (Crystal/Mount, Biomeda Corp., Foster City, CA, USA) was applied over the retina and allowed to dry. The flat-mounted retina was examined by fluorescence microscopy (Nikon SMZ1500 with P-FLA fluorescence attachment, Nikon, Tokyo, Japan).

\section{Histopathology}

Under deep anesthesia induced by intraperitoneal injection of pentobarbital sodium $(25 \mathrm{mg} / \mathrm{kg}$ body weight, Nembutal, Dainihonseiyaku, Osaka, Japan), the eyes were enucleated for conventional histopathologic studies and placed in a fixative (mixture of $2.5 \%$ paraformaldehyde and $1 \%$ glutaraldehyde in $0.15 \mathrm{M}$ phosphate buffer) to avoid artificial retinal detachment. The fixed eyes were washed in $0.1 \% \mathrm{~mol} / 1$ cacodylate buffer and embedded in paraffin. The paraffin block was sectioned to $4 \mu \mathrm{m}$ and stained with hematoxylin and eosin for conventional histopathologic examination. As reported previously [27], DR was identified when large retinal folds mimicking tractional retinal detachment and/or extensive leakage of fluorescein around the optic disc were observed. In this study, the left eyes were examined by fluorescein angiomicroscopy or histopathology.

\section{Biomicroscopy of Cataract}

The pupils were fully dilated with a topical ophthalmic solution containing tropicamide $5 \%$ and phenylephrine hydrochloride 5\%, and the anterior segment including the lens was observed and photographed in both eyes of all rats.

\section{Measurement of Sorbitol and Fructose}

The retina and lens were separated from the enucleated eye and homogenized in distilled water. Trichloro-acetic acid (TCA) and internal standard (D-sorbitol-d4 and D-fructosed2) were added to the homogenate followed by centrifugation at $10,000 \mathrm{xg}$ for 5 minutes at $4^{\circ} \mathrm{C}$ to obtain the supernatant fraction. To remove the TCA, the supernatant fraction was washed with ethyl ether. Sorbitol and fructose in the supernatant fraction were converted to sorbitol acetate derivative and fructose acetate derivative according to the method described by Guerrant and Moss [28] (highperformance liquid chromatography with the HP1050, Hewlett Packard, Palo Alto, CA, USA) and mass spectrometry (TSQ, Finnigan Mat, San Jose, CA, USA) using a Cadenza CD-C18 column $(75 \times 2.0 \mathrm{~mm}$, internal diameter $3 \mathrm{~mm}$, Imtakt, Kyoto, Japan).

\section{Measurement of Reduced Glutathione (GSH)}

The retinas and lenses were separated from the enucleated eyes and homogenized after the addition of icecold 5\% metaphosphoric acid. The tissue homogenates were centrifuged at $10,000 \mathrm{xg}$ for $20 \mathrm{~min}$ at $4^{\circ} \mathrm{C}$. Aliquots of the supernatant fractions were used to determine the GSH with a colorimetric assay kit (Bioxytech GSH-400) supplied by Oxis Research (Portland, OR, USA).

\section{Measurement of VEGF}

Ocular fluid (aqueous and vitreous) was collected from the enucleated eyes and the VEGF levels were measured with a sandwich enzyme immunoassay technique (ELISA) using a mouse VEGF immunoassay (R\&D System, 
Minneapolis, MN, USA), according to the manufacturer's instruction.

\section{Measurement of 8-Hydroxy-2'-Deoxyguanosine (8-OHdG)}

The rats were housed in metabolic cages 39 weeks after the onset of diabetes. Urine was collected over $24 \mathrm{~h}$, the samples were centrifuged at $1,700 \mathrm{xg}$ for $10 \mathrm{~min}$ at $4^{\circ} \mathrm{C}$, and the 8-OHdG levels in the supernatant were measured with an ELISA kit (8-OHdG check; Japan Institute for the Control of Aging, Fukuroi, Japan), according to the manufacturer's instructions.

The retina, lens, and ocular fluid samples were obtained from enucleated eyes except for eyes in the histopathology study and allocated for the previously mentioned analysis. Therefore, the numbers of eyes in each analysis were smaller than the number of rats used.

\section{Statistical Analysis}

The prevalence rates of DR and cataract were evaluated by the chi-square for independence test. The Student $t$ test was used to compare the normal SD rats and untreated SDT rats. Analysis of variance and Dunnett's multiple comparison test were used to compare the differences among the three groups of SDT rats. The values are expressed as the mean \pm SE. $p<0.05$ was considered to be statistically significant.

\section{RESULTS}

\section{Body Weight, Plasma Glucose, and Glycated Hemoglobin}

Table 1 shows the weights, plasma glucose, and glycated hemoglobin values. The mean body weight of the nondiabetic normal control SD rats (mean \pm SE, $900 \pm 24 \mathrm{~g}$ ) was significantly $(\mathrm{p}<0.001)$ higher than that of the untreated SDT rats $(364 \pm 14 \mathrm{~g})$. Fidarestat had no significant effect on body weight among the three groups of SDT rats.

Table 1. Body Weight, Plasma Glucose, and Glycated Hemoglobin

\begin{tabular}{|c|c|c|c|}
\hline & $\begin{array}{c}\text { Body } \\
\text { Weight (g) }\end{array}$ & $\begin{array}{c}\text { Plasma } \\
\text { Glucose (mmol/l) }\end{array}$ & $\begin{array}{c}\text { Glycated } \\
\text { Hemoglobin (\%) }\end{array}$ \\
\hline \hline Normal SD rat & $900 \pm 24$ & $9.3 \pm 0.4$ & $3.5 \pm 0.1$ \\
\hline Untreated & $364 \pm 14^{*}$ & $42.8 \pm 3.4^{*}$ & $13.8 \pm 0.7^{*}$ \\
\hline $\begin{array}{c}\text { Low-dose } \\
\text { fidarestat group }\end{array}$ & $366 \pm 10$ & $48.6 \pm 3.9$ & $16.4 \pm 0.4$ \\
\hline $\begin{array}{c}\text { High-dose } \\
\text { fidarestat group }\end{array}$ & $332 \pm 15$ & $46.2 \pm 2.8$ & $14.7 \pm 0.5$ \\
*p $<0.001$ vs normal SD rats.
\end{tabular}

The mean plasma glucose level of the non-diabetic normal SD rats (mean $\pm \mathrm{SE}, \quad 9.3 \pm 0.4 \mathrm{mmol} / \mathrm{l}$ ) was significantly $(\mathrm{p}<0.001)$ lower than that of the untreated SDT rats $(42.8 \pm 3.4 \mathrm{mmol} / \mathrm{l})$. Fidarestat had no significant effect on the plasma glucose level among the three groups of SDT rats.

The mean glycated hemoglobin concentration of the nondiabetic normal SD rats (mean \pm SE, $3.5 \pm 0.1 \%$ ) was significantly $(p<0.001)$ lower than that of the untreated SDT rats $(13.8 \pm 0.7 \%)$. The mean glycated hemoglobin concentration in the low-dose fidarestat SDT rats $(16.4 \pm 0.4 \%)$, but not the high-dose fidarestat SDT rats $(14.7 \pm 0.5 \%)$, was higher than that of the untreated SDT rats $(13.8 \pm 0.7 \%)$ $(\mathrm{p}<0.05)$.

\section{Prevalence of DR}

DR developed less often in the low- $(0 / 14$ eyes, $0 \%)$ $(p<0.001)$ and high-dose groups $(0 / 21$ eyes, $0 \%)(p<0.001)$ than in the untreated SDT rats (12/18 eyes, 66.6\%) (Table 2). The typical pathological changes of DR, i.e., the large retinal folds mimicking tractional retinal detachment, were observed in most untreated SDT rats but not in the low-dose and high-dose fidarestat-treated SDT rats (Fig. 1A). The typical angiomicroscopic changes of DR, i.e., extensive leakage of fluorescein around the optic disc, were observed in most untreated SDT rats but not in the low- or high-dose groups (Fig. 1B).

Table 2. Prevalence of DR

\begin{tabular}{|c|c|c|}
\hline & Retinopathy (+) & Retinopathy (-) \\
\hline \hline Normal SD rat & $0 \%(0 / 10$ eyes $)$ & $100 \%(10 / 10$ eyes $)$ \\
\hline Untreated & $66.6 \%(12 / 18$ eyes $)$ & $33.3 \%(6 / 18$ eyes $)$ \\
\hline $\begin{array}{c}\text { Low-dose } \\
\text { fidarestat group }\end{array}$ & $0 \%(0 / 14$ eyes $) *$ & $100 \%(14 / 14$ eyes $)$ \\
\hline $\begin{array}{c}\text { High-dose } \\
\text { fidarestat group }\end{array}$ & $0 \%(0 / 21$ eyes $) *$ & $100 \%(21 / 21$ eyes $)$ \\
\hline *p $<0.001$ vs untreated SDT rats.
\end{tabular}

\section{Prevalence of Cataract}

Cataract developed less frequently in the low-dose $(3 / 28$ eyes, $10.7 \%)(\mathrm{p}<0.001)$ and high-dose fidarestat SDT rats $(2 / 42$ eyes, $4.8 \%)(\mathrm{p}<0.001)$ than in the untreated SDT rats $(36 / 36$ eyes, $100 \%)$ (Table 3). Typical mature diabetic cataracts were observed in most untreated SDT rats but not in the low- and high-dose groups (Fig. 1C).

\section{Sorbitol and Fructose}

The retinal sorbitol levels were lower in the non-diabetic normal SD rats (mean $\pm \mathrm{SE}, 1.1 \pm 0.1 \mathrm{nmol} / \mathrm{mg}$ protein, $\mathrm{n}=4$ ) $(\mathrm{p}<0.05)$, low-dose fidarestat SDT rats $(2.7 \pm 1.1 \mathrm{nmol} / \mathrm{mg}$ protein, $n=3)(\mathrm{p}<0.01)$ and high-dose fidarestat SDT rats $(0.7 \pm 0.2 \mathrm{nmol} / \mathrm{mg}$ protein, $\mathrm{n}=4)(\mathrm{p}<0.001)$ than in the untreated SDT rats $(23.2 \pm 4.7 \mathrm{nmol} / \mathrm{mg}$ protein, $\mathrm{n}=3$ ) (Fig. 2A).

The lens sorbitol levels were lower in the non-diabetic normal SD rats $(3.1 \pm 0.2 \mathrm{nmol} / \mathrm{mg}$ protein, $\mathrm{n}=4)(\mathrm{p}<0.01)$, low-dose fidarestat SDT rats $(30.0 \pm 3.3 \mathrm{nmol} / \mathrm{mg}$ protein, $\mathrm{n}=3)(\mathrm{p}<0.01)$, and high-dose fidarestat SDT rats $(5.9 \pm 0.6$ $\mathrm{nmol} / \mathrm{mg}$ protein, $\mathrm{n}=4)(\mathrm{p}<0.001)$ than in the untreated SDT rats $(123.9 \pm 29.6 \mathrm{nmol} / \mathrm{mg}$ protein, $\mathrm{n}=3)$ (Fig. 2B).

The retinal fructose levels were lower in the non-diabetic normal SD rats $(3.7 \pm 0.9 \mathrm{nmol} / \mathrm{mg}$ protein, $\mathrm{n}=4)(\mathrm{p}<0.001)$ but not in the low-dose fidarestat SDT rats $(6.8 \pm 5.0 \mathrm{nmol} / \mathrm{mg}$ protein, $n=3$ ) (not significant (NS)) and high-dose fidarestat SDT rats $(6.3 \pm 2.5 \mathrm{nmol} / \mathrm{mg}$ protein, $\mathrm{n}=4)(\mathrm{NS})$ compared 


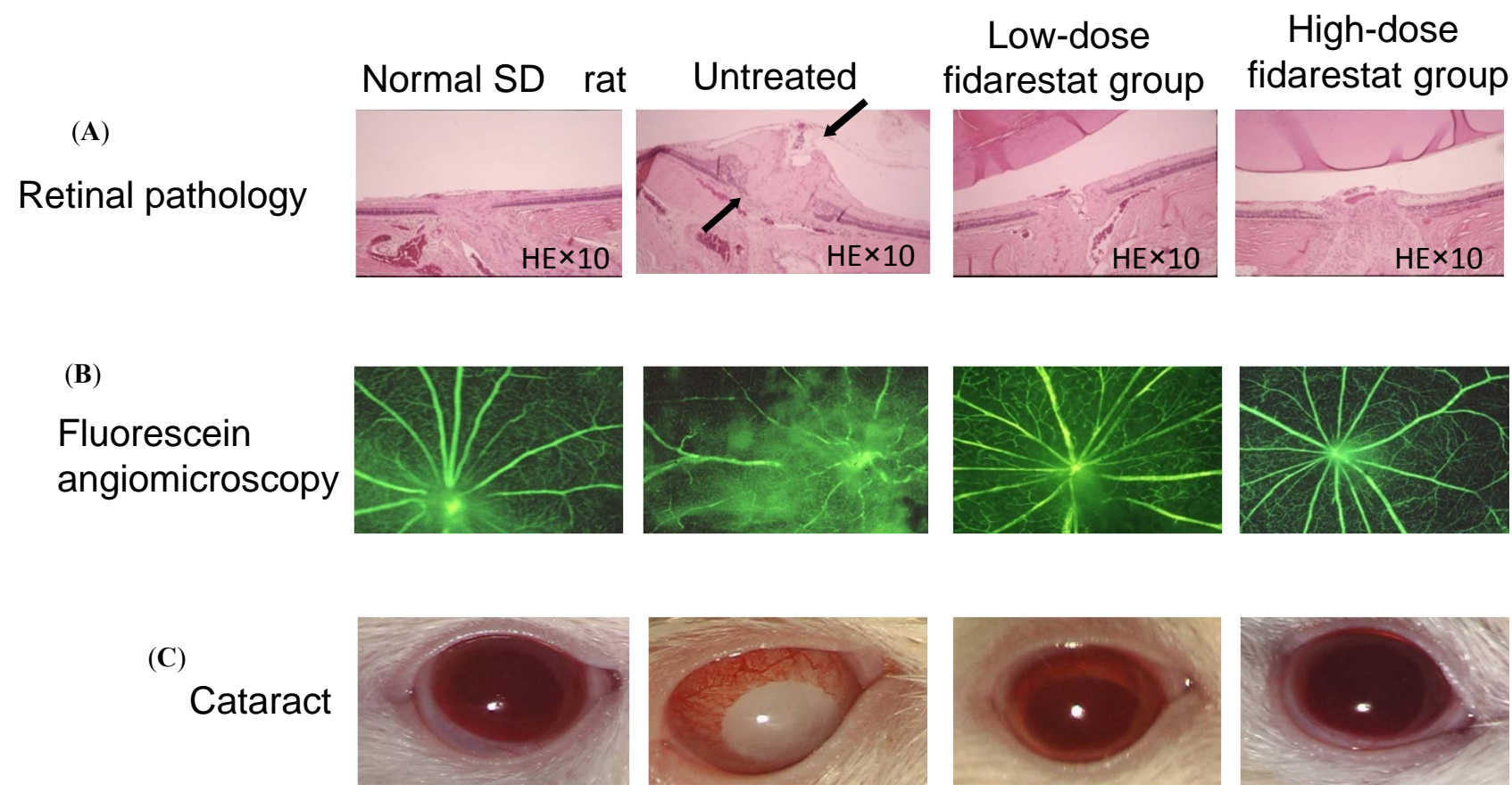

Fig. (1). Effect of fidarestat on DR and cataract. First row (A): Large retinal folds mimic tractional retinal detachment (arrows) in untreated SDT rats but not in low-dose fidarestat-treated SDT rats, high-dose fidarestat-treated SDT rats, and non-diabetic normal control SD rats. Second row: (B) Extensive leakage of fluorescein around the optic disc in an untreated SDT rat but not in a low-dose fidarestat-treated SDT rat, high-dose fidarestat-treated SDT rat, and non-diabetic normal control SD rat. Third row: (C) Mature cataract in an untreated SDT rat but not in a low-dose fidarestat-treated SDT rat, high-dose fidarestat-treated SDT rat, and non-diabetic normal control SD rat.

with the untreated SDT rats $(13.7 \pm 1.2 \mathrm{nmol} / \mathrm{mg}$ protein, $\mathrm{n}=3)$ (Fig. 3A).

The lens fructose levels were lower in the normal nondiabetic SD rat group $(8.2 \pm 0.4 \mathrm{nmol} / \mathrm{mg}$ protein, $\mathrm{n}=4)$ $(\mathrm{p}<0.01)$, the low-dose fidarestat SDT rats $(53.3 \pm 2.6$ $\mathrm{nmol} / \mathrm{mg}$ protein, $\mathrm{n}=3)(\mathrm{p}<0.01)$, and the high-dose fidarestat SDT rats $(21.4 \pm 0.8 \mathrm{nmol} / \mathrm{mg}$ protein, $\mathrm{n}=4)(\mathrm{p}<0.001)$ than in the untreated SDT rats $(154.6 \pm 35.9 \mathrm{nmol} / \mathrm{mg}$ protein, $\mathrm{n}=3)$ (Fig. 3B).

Table 3. Prevalence of Cataract

\begin{tabular}{|c|c|c|}
\hline & Cataract (+) & Cataract (-) \\
\hline \hline Normal SD rat & $0 \%(0 / 20$ eyes $)$ & $100 \%(20 / 20$ eyes $)$ \\
\hline Untreated & $100 \%(36 / 36$ eyes $)$ & $0 \%(0 / 36$ eyes $)$ \\
\hline $\begin{array}{c}\text { Low-dose } \\
\text { Fidarestat group }\end{array}$ & $10.7 \%(3 / 28$ eyes $) *$ & $89.3 \%(25 / 28$ eyes $)$ \\
\hline $\begin{array}{c}\text { High-dose } \\
\text { Fidarestat group }\end{array}$ & $4.8 \%(2 / 42$ eyes $) *$ & $95.2 \%(40 / 42$ eyes $)$ \\
\hline${ }^{*}$ p $<0.001$ vs untreated SDT rats.
\end{tabular}

\section{GSH}

The retinal GSH levels were higher in the non-diabetic normal SD rats (mean $\pm \mathrm{SE}, 52.2 \pm 5.8 \mu \mathrm{mol} / \mathrm{mg}$ protein, $\mathrm{n}=10$ ) $(\mathrm{p}<0.01)$ and the high-dose fidarestat SDT rats $(63.3 \pm 14.6$ $\mu \mathrm{mol} / \mathrm{mg}$ protein, $\mathrm{n}=9)(\mathrm{p}<0.05)$ but not in the low-dose fidarestat SDT rats $(46.8 \pm 8.2 \mu \mathrm{mol} / \mathrm{mg}$ protein, $\mathrm{n}=8)(\mathrm{NS})$ compared with the untreated SDT rats $(30.3 \pm 2.0 \mu \mathrm{mol} / \mathrm{mg}$ protein, $\mathrm{n}=10$ ) (Fig. 4A).

The lens GSH levels were higher in the non-diabetic normal SD rats $(29.0 \pm 2.7 \mu \mathrm{mol} / \mathrm{mg}$ protein, $\mathrm{n}=10)(\mathrm{p}<0.001)$,

the low-dose fidarestat SDT rats $(24.7 \pm 2.8 \mu \mathrm{mol} / \mathrm{mg}$ protein, $\mathrm{n}=8)(\mathrm{p}<0.001)$, and the high-dose fidarestat SDT rats $(26.9 \pm 3.6 \mu \mathrm{mol} / \mathrm{mg}$ protein, $\mathrm{n}=10)(\mathrm{p}<0.001)$ compared with the untreated SDT rats $(1.6 \pm 0.4 \mu \mathrm{mol} / \mathrm{mg}$ protein, $\mathrm{n}=10)$ (Fig. 4B).

\section{VEGF}

The VEGF levels in the ocular fluid were lower in the non-diabetic normal SD rats (mean \pm SE, $40.4 \pm 10.0 \mathrm{pg} / \mathrm{m}$, $\mathrm{n}=8)(\mathrm{p}<0.01)$, the low-dose fidarestat SDT rats $(65.3 \pm 4.5$ $\mathrm{pg} / \mathrm{ml}, \mathrm{n}=6)(\mathrm{p}<0.05)$, and the high-dose fidarestat SDT rats $(47.7 \pm 10 \mathrm{pg} / \mathrm{ml}, \mathrm{n}=9)(\mathrm{p}<0.001)$ than in the untreated SDT rats $(324.7 \pm 76.4 \mathrm{pg} / \mathrm{ml}, \mathrm{n}=8)$ (Fig. 5).

\section{8-OHdG}

The urinary 8-OHdG levels were lower in the nondiabetic normal SD rats (mean \pm SE, $0.73 \pm 0.11 \mathrm{ng} / \mathrm{mg}$ creatinine, $\mathrm{n}=8)(\mathrm{p}<0.01)$ than in the low-dose fidarestat SDT rats $(4.57 \pm 0.42 \mathrm{ng} / \mathrm{mg}$ creatinine, $\mathrm{n}=6)(\mathrm{NS})$ and high-dose fidarestat SDT rats $(3.58 \pm 0.70 \mathrm{ng} / \mathrm{mg}$ creatinine, $\mathrm{n}=8)$ $(\mathrm{p}=(\mathrm{NS}))$ compared with the untreated SDT rats $(6.04 \pm 1.28$ $\mathrm{ng} / \mathrm{ml}, \mathrm{n}=8$ ) (Fig. 6). 


\section{DISCUSSION}

The favorable effects of fidarestat on early DR in STZinduced diabetic rats have been reported previously [21]. Fidarestat decreased the number of microaneurysms and pericytes and basement membrane thickness. However, that report confirmed only the decreased retinal sorbitol and coexisting vascular retinal changes. Subsequent experimental

(A)

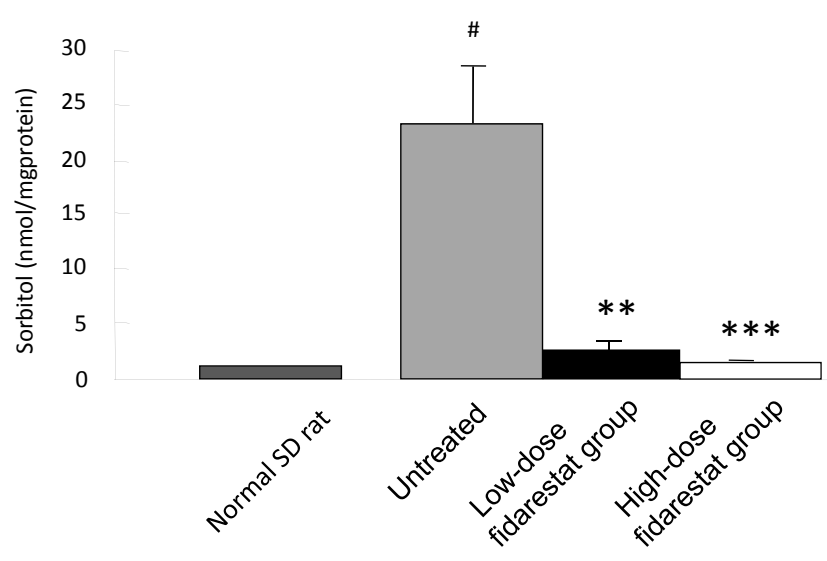

(B)

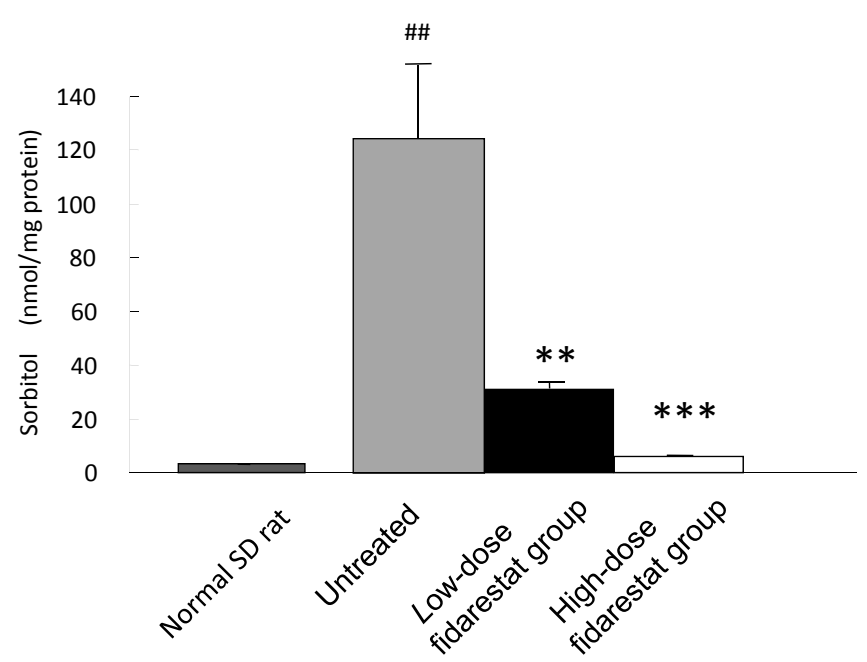

Fig. (2). Retinal (A) and lens (B) sorbitol levels. A: $\#$ p $<0.05$ vs normal SD rats. ${ }^{* *}, * * * \mathrm{p}<0.01, \mathrm{p}<0.001$ vs untreated SDT rats. $\mathbf{B}$ : \#\# $<0.01$ vs normal SD rat. ${ }^{* *},{ }^{* * *} \mathrm{p}<0.01, \mathrm{p}<0.001$ vs untreated SDT rats.

studies of STZ-induced diabetic rats have suggested that fidarestat prevents oxidative stress and VEGF production in tissues that are targets for diabetic complications [19, 20]. The limitation of these studies regarding ocular diabetic complications is that STZ-induced rats develop only early DR with microaneurysms and thickening of the basement membranes of the retinal capillaries without proliferative changes. In contrast, the SDT rats have more advanced changes with extensive vascular hyperpermeability and tractional retinal detachment with retinal thickening around the optic disc [27, 29, 30]. Hyperglycemia is also more severe in the SDT rats than the STZ-induced diabetic rats $[29,30]$. Therefore, activation of the polyol pathway is presumably more extensive and oxidative stress and VEGF production much higher in the SDT rats than in the STZinduced diabetic rats. In the current study, we tested the prophylactic effect of fidarestat on diabetic ocular complications in SDT rats, which had very high glucose and glycated hemoglobin levels with and without fidarestat. Therefore, inhibition of cataract and retinopathy with fidarestat could not be attributed to improved glycemic

control. The retinal and lens sorbitol levels in the fidarestattreated SDT rats were significantly lower than in the untreated SDT rats. Although reduction of fructose was not as significant, the effect of AR inhibition was marked in the current in vivo study.

(A)

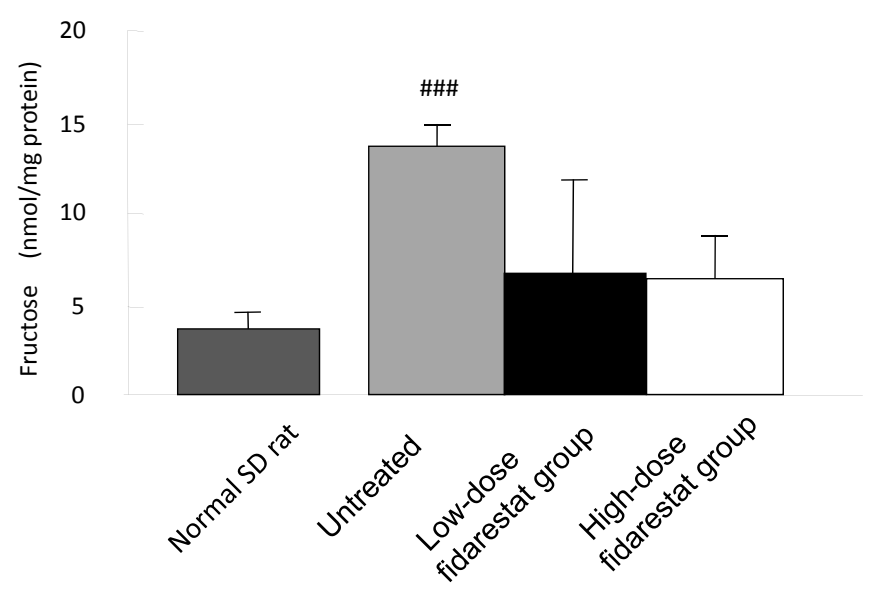

(B)

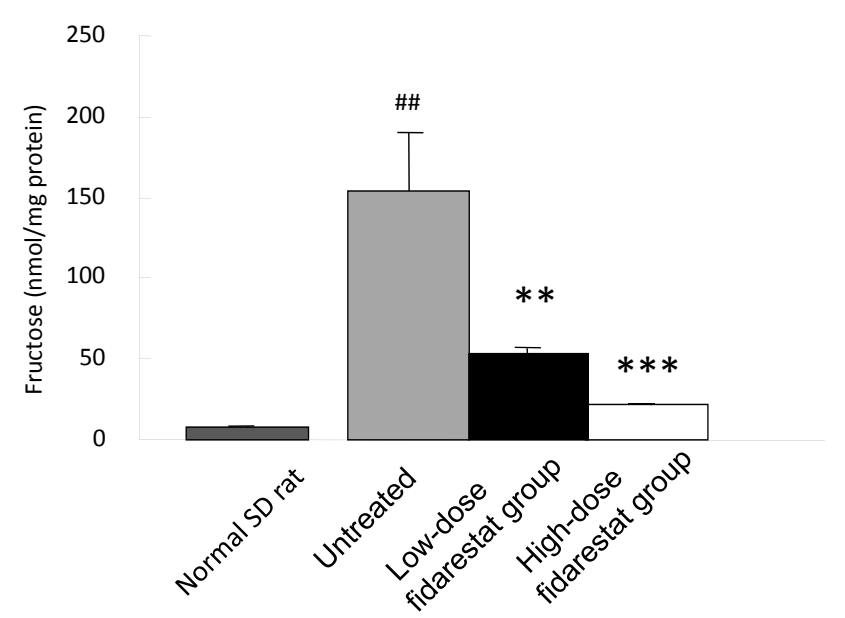

Fig. (3). Retinal (A) and lens (B) fructose levels. A: $\# \# \# p<0.001$ vs normal SD rats. B: $\# \# p<0.01$ vs normal SD rats. ${ }^{* *}, * * * p<0.01$, $\mathrm{p}<0.001$ vs untreated SDT rats.

Oxidative stress is an important factor in the pathogenesis of diabetic complications [31-33]. GSH plays an important role in polyol pathway activation. In particular, GSH consumption is the most important factor in the development of diabetic cataract $[34,35]$. GSH levels also contribute to the pathogenesis of DR [36]. It also has been reported that fidarestat prevents GSH consumption in retinal pericytes cultured in a high concentration of glucose [37]. 
The SDT rats had low GSH levels in the lens, and fidarestat raised those levels significantly. This antioxidative effect of fidarestat also was seen in the retina of rats treated with the high-dose fidarestat. 8-OHdG, also a good marker of systemic oxidative stress in diabetes [38-40], is excreted in the urine; the urinary $8-\mathrm{OHdG}$ level was significantly higher in untreated SDT rats than in normal SD rats. However, the effect of fidarestat treatment on 8-OHdG was not significant.

(A)

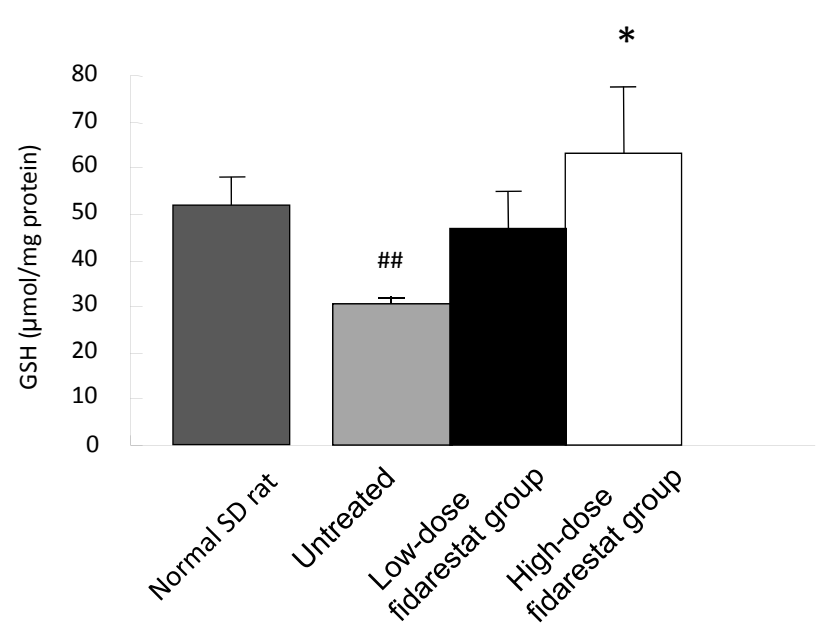

(B)

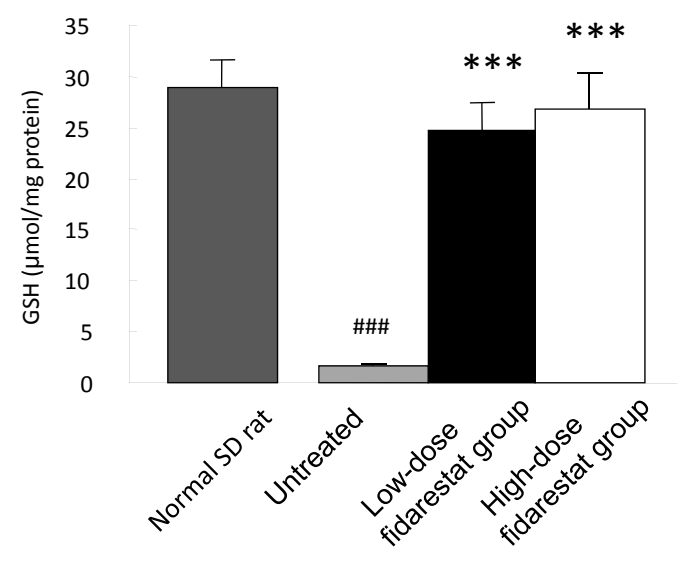

Fig. (4). Retinal (A) and lens (B) GSH levels. A: \#\#P<0.01 vs normal SD rats. ${ }^{*} \mathrm{p}<0.05$ vs untreated SDT rats. B: \#\#\#p $<0.001$ vs normal SD rats. ${ }^{* * *} \mathrm{p}<0.001$ vs untreated SDT rats.

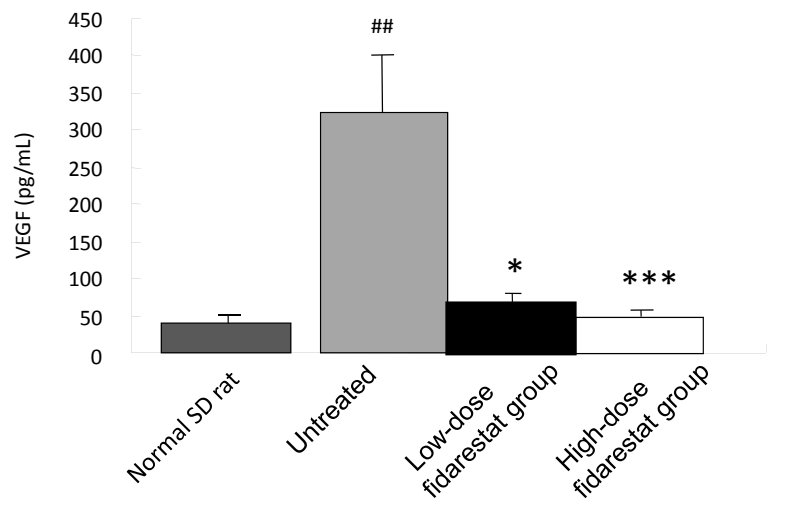

Fig. (5). VEGF levels in the ocular fluid. \#\#p $<0.01$ vs normal SD rats. ${ }^{*}, * * \mathrm{p}<0.05, \mathrm{p}<0.001$ vs untreated SDT rats.

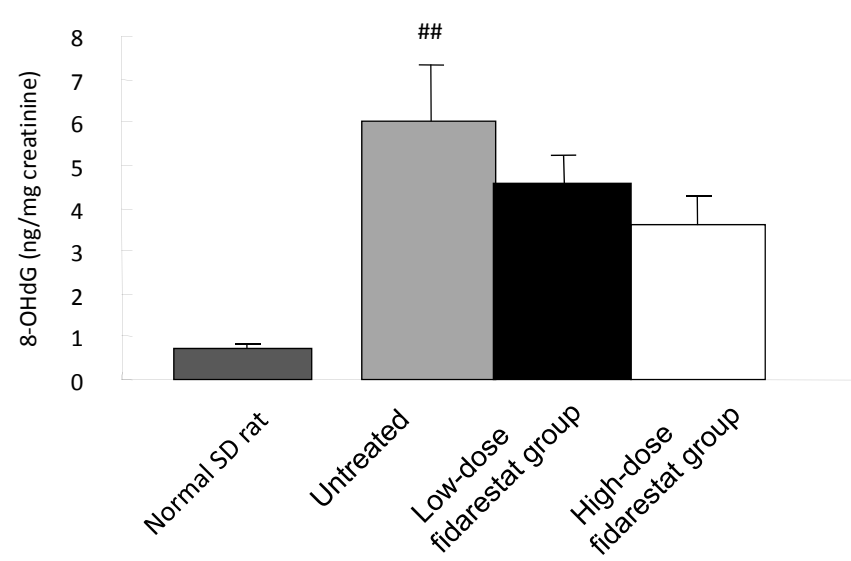

Fig. (6). Urinary 8-OHdG levels. \#\#p $<0.01$ vs normal SD rats.

VEGF is the most important molecule that induces PDR $[41,42]$. VEGF induces vascular hyperpermeability and retinal neovascularization and eventually neovascular glaucoma [43]. Retinal neovascularization is the main cause of vitreous hemorrhage and diabetic tractional retinal detachment. Neovascular glaucoma complicated with PDR is the most tragic consequence of VEGF production. Although the untreated SDT rats did not have marked retinal neovascularization, the vascular hyperpermeability was prominent (Fig. 1B). The VEGF levels in the ocular fluid were inhibited significantly to almost normal levels in the low- and high-dose groups.

In conclusion, activation of the polyol pathway induces many biologic effects, such as oxidative stress, activation of $\mathrm{PKC}$, and AGE accumulation, that induces VEGF. AR is a key enzyme in the polyol pathway. In the current study, fidarestat clearly inhibited AR and prevented diabetic ocular complications because of the antioxidative stress and antiVEGF mechanisms in SDT rats. Fidarestat seems to prevent diabetic ocular complications, which warrants a clinical trial.

\section{ACKNOWLEDGEMENT}

We thank Professor Wilfred Y. Fujimoto of the University of Washington for his helpful advice and discussion.

\section{REFERENCES}

[1] Writing team for the Diabetes Control and Complications Trial/Epidemiology of Diabetes Interventions and Complication Research Group. Effect of intensive therapy on the microvascular complications of type 1 diabetes mellitus. JAMA 2002; 287: 25639.

[2] The effect of intensive treatment of diabetes on the development and progression of long-term complications in insulin-dependent diabetes mellitus. The Diabetes Control and Complications Trial Research Group. N Engl J Med 1993; 329: 977-86.

[3] Stratton IM, Kohner EM, Aldington SJ, et al. UKPDS 50: risk factors for incidence and progression of retinopathy in Type II diabetes over 6 years from diagnosis. Diabetologia 2001; 44: 15663.

[4] Hotta N, Nakamura J, Sakakibara F, et al. Electroretinogram in sucrose-fed diabetic rats treated with an aldose reductase inhibitor or an anticoagulant. Am J Physiol 1997; 273: E965-71.

[5] Robison WG Jr., Nagata M, Tillis TN, Laver N, Kinoshita JH. Aldose reductase and pericyte-endothelial cell contacts in retina and optic nerve. Invest Ophthalmol Vis Sci 1989; 30: 2293-9.

[6] Aiello LP, Bursell SE, Clermont A, et al. Vascular endothelial growth factor-induced retinal permeability is mediated by protein kinase $\mathrm{C}$ in vivo and suppressed by an orally effective betaisoform-selective inhibitor. Diabetes 1997; 46: 1473-80. 
[7] Lee TS, MacGregor LC, Fluharty SJ, King GL. Differential regulation of protein kinase $\mathrm{C}$ and $(\mathrm{Na}, \mathrm{K})$-adenosine triphosphatase activities by elevated glucose levels in retinal capillary endothelial cells. J Clin Invest 1989; 83: 90-4.

[8] Nakamura J, Kato K, Hamada Y, et al. A protein kinase C-betaselective inhibitor ameliorates neural dysfunction in streptozotocininduced diabetic rats. Diabetes 1999; 48: 2090-5.

[9] Kuroki M, Voest EE, Amano S, et al. Reactive oxygen intermediates increase vascular endothelial growth factor expression in vitro and in vivo. J Clin Invest 1996; 98: 1667-5.

[10] Altomare E, Grattagliano I, Vendemaile G, Micelli-Ferrari T, Signorile A, Cardia L. Oxidative protein damage in human diabetic eye: evidence of a retinal participation. Eur J Clin Invest 1997; 27 : 141-7.

[11] Hammes HP, Brownlee M, Lin J, Schleicher E, Bretzel RG. Diabetic retinopathy risk correlates with intracellular concentrations of the glycoxidation product Nepsilon(carboxymethyl) lysine independently of glycohaemoglobin concentrations. Diabetologia 1999; 42: 603-7.

[12] Hammes HP, Wellensiek B, Kloting I, Sickel E, Bretzel RG, Brownlee $M$. The relationship of glycaemic level to advanced glycation end-product (AGE) accumulation and retinal pathology in the spontaneous diabetic hamster. Diabetologia 1998; 41: 16570 .

[13] Murata T, Nagai R, Ishibashi T, Inomuta H, Ikeda K, Horiuchi S. The relationship between accumulation of advanced glycation end products and expression of vascular endothelial growth factor in human diabetic retinas. Diabetologia 1997; 40: 764-9.

[14] Dvornik E, Simard-Duquesne N, Krami M, et al. Polyol accumulation in galactosemic and diabetic rats: control by an aldose reductase inhibitor. Science 1973; 182: 1146-8.

[15] Yeh LA, Rafford CE, Beyer TA, Hutson NJ. Effects of the aldose reductase inhibitor sorbinil on the isolated cultured rat lens. Metabolism 1986; 35: 4-9.

[16] Sun W, Oates PJ, Coutcher JB, Gerhardinger C, Lorenzi M. A selective aldose reductase inhibitor of a new structural class prevents or reverses early retinal abnormalities in experimental diabetic retinopathy. Diabetes 2006; 55: 2757-62.

[17] Robinson WG, Jr., Laver NM, Jacot JL, et al. Diabetic-like retinopathy ameliorated with the aldose reductase inhibitor WAY121,509. Invest Ophthalmol Vis Sci 1996; 37: 1149-56.

[18] Okuda J, Yashima K, Inagaki K, Miwa I. Effects of an aldose reductase inhibitor, 1-[(p-bromophenyl)-sulfonyl]hydantoin, on cataract formation and tissue polyol levels in galactosemic rats. Chem Pharm Bull (Tokyo) 1985; 33: 2990-5.

[19] Obrosova IG, Pacher P, Szabo C, et al. Aldose reductase inhibition counteracts oxidative-nitrosative stress and poly(ADP-ribose) polymerase activation in tissue sites for diabetes complications. Diabetes 2005; 54: 234-42.

[20] Obrosova IG, Minchenko AG, Vasupuram R, et al. Aldose reductase inhibitor fidarestat prevents retinal oxidative stress and vascular endothelial growth factor overexpression in streptozotocin-diabetic rats. Diabetes 2003; 52: 864-71.

[21] Kato N, Yashima S, Suzuki T, Nakayama Y, Jomori T. Long-term treatment with fidarestat suppresses the development of diabetic retinopathy in STZ-induced diabetic rats. J Diabetes Complications 2003; 17: 374-9.

[22] Robison WG, Jr., Kador PF, Kinoshita JH. Retinal capillaries: basement membrane thickening by galactosemia prevented with aldose reductase inhibitor. Science 1983; 221: 1177-9.

[23] Frank RN, Keirn RJ, Kennedy A, Frank KW. Galactose-induced retinal capillary basement membrane thickening: prevention by Sorbinil. Invest Ophthalmol Vis Sci 1983; 24: 1519-24.

[24] A randomized trial of sorbinil, an aldose reductase inhibitor, in diabetic retinopathy. Sorbinil Retinopathy Trial Research Group. Arch Ophthalmol 1990; 108: 1234-44.
[25] Hotta N, Toyota T, Matsuoka K, et al. Clinical efficacy of fidarestat, a novel aldose reductase inhibitor, for diabetic peripheral neuropathy: a 52-week multicenter placebo-controlled double-blind parallel group study. Diabetes Care 2001; 24: 1776-82.

[26] D'Amato R, Wesolowski E, Smith LE. Microscopic visualization of the retina by angiography with high-molecular-weight fluoresceinlabeled dextrans in the mouse. Microvasc Res 1993; 46: 135-42.

[27] Kakehashi A, Saito Y, Mori K, et al. Characteristics of diabetic retinopathy in SDT rats. Diabetes Metab Res Rev 2006; 22: 45561 .

[28] Guerrant GO, Moss CW. Determinations of monosaccharide as aldononitrite, o-methyleoxime, alditol, and cyclitol acetate derivatives by gas chromatography. Anal Chem 1984; 56: 633-8.

[29] Shinohara M, Masuyama T, Kakehashi A. The spontaneously diabetic Torii (SDT) rat with retinopathy lesions resembling those of humans. In: Shafrir E, Ed. Animal models of diabetes.-frontiers in research.2nd ed. CRC Press, Boca Raton(FL): 2007; pp. 311-21.

[30] Shinohara M, Masuyama T, Shoda T, et al. A new spontaneously diabetic non-obese Torii rat strain with severe ocular complications. Int J Exp Diabetes Res 2000; 1: 89-100.

[31] Van Dam PS, Van Asbeck BS, Erkelens DW, Marx JJ, Gispen $\mathrm{WH}$, Bravenboer B. The role of oxidative stress in neuropathy and other diabetic complications. Diabetes Metab Rev 1995; 11: 18192.

[32] Giugliano D, Ceriello A, Paolisso G. Oxidative stress and diabetic vascular complications. Diabetes Care 1996; 19: 257-67.

[33] Ceriello A. New insights on oxidative stress and diabetic complications may lead to a "causal" antioxidant therapy. Diabetes Care 2003; 26: 1589-96.

[34] Mitton KP, Dean PA, Dzialoszynski T, Xiong H, Sanford SE, Trevithick JR. Modelling cortical cataractogenesis. 13. Early effects on lens ATP/ADP and glutathione in the streptozotocin rat model of the diabetic cataract. Exp Eye Res 1993; 56: 187-98.

[35] Ross WM, Creighton MO, Trevithick JR, Stewart-DeHaan PJ, Sanwal M. Modelling cortical cataractogenesis: VI. Induction by glucose in vitro or in diabetic rats: prevention and reversal by glutathione. Exp Eye Res 1983; 37: 559-73.

[36] Sampathkumar R, Balasubramanyam M, Tara C, Rema M, Mohan V. Association of hypoglutathionemia with reduced $\mathrm{Na}+\mathrm{K}+$ ATPase activity in type 2 diabetes and microangiopathy. Mol Cell Biochem 2006; 282: 169-76.

[37] Miwa K, Nakamura J, Hamada Y, et al. The role of polyol pathway in glucose-induced apoptosis of cultured retinal pericytes. Diabetes Res Clin Pract 2003; 60: 1-9.

[38] Suzuki S, Hinokio Y, Komatu K, et al. Oxidative damage to mitochondrial DNA and its relationship to diabetic complications. Diabetes Res Clin Pract 1999; 45: 161-8.

[39] Park KS, Kim JH, Kim MS, et al. Effects of insulin and antioxidant on plasma 8-hydroxyguanine and tissue 8-hydroxydeoxyguanosine in streptozotocin-induced diabetic rats. Diabetes 2001; 50: 283741 .

[40] Kakimoto M, Inoguchi T, Sonta T, et al. Accumulation of 8hydroxy-2'-deoxyguanosine and mitochondrial DNA deletion in kidney of diabetic rats. Diabetes 2002; 51: 1588-95.

[41] Aiello LP, Pierce EA, Foley ED, et al. Suppression of retinal neovascularization in vivo by inhibition of vascular endothelial growth factor (VEGF) using soluble VEGF-receptor chimeric proteins. Proc Natl Acad Sci U S A 1995; 92: 10457-61.

42] Pe'er J, Folberg R, Itin A, Gnessin H, Hemo I, Keshet E. Upregulated expression of vascular endothelial growth factor in proliferative diabetic retinopathy. Br J Ophthalmol 1996; 80: 241 5 .

[43] Tolentino MJ, Miller JW, Gragoudas ES, Chatzistefanou K, Ferrara N, Adamis AP. Vascular endothelial growth factor is sufficient to produce iris neovascularization and neovascular glaucoma in a nonhuman primate. Arch Ophthalmol 1996; 114: 964-70. 